\title{
Synthesis and Cytotoxic Evaluation of Steroidal Copper (Cu (II)) Complexes
}

\author{
Yanmin Huang, ${ }^{1}$ Erbin Kong, ${ }^{1}$ Junyan Zhan, ${ }^{1}$ Shuang Chen, ${ }^{1}$ Chunfang Gan, ${ }^{1}$ \\ Zhiping Liu, ${ }^{1}$ Liping Pang, ${ }^{1}$ and Jianguo $\mathrm{Cui}^{1,2}$ \\ ${ }^{1}$ Key Laboratory of Beibu Gulf Environment Change and Resources Utilization, College of Chemistry and Material Science, \\ Guangxi Teachers Education University, Nanning 530001, China \\ ${ }^{2}$ Guangxi Colleges and University Key Laboratory of Beibu Gulf Oil and Natural Gas Resource Effective Utilization, \\ Qizhou University, Qizhou, China
}

Correspondence should be addressed to Jianguo Cui; cuijg1954@126.com

Received 21 November 2016; Accepted 24 April 2017; Published 18 October 2017

Academic Editor: Giovanni Natile

Copyright (C) 2017 Yanmin Huang et al. This is an open access article distributed under the Creative Commons Attribution License, which permits unrestricted use, distribution, and reproduction in any medium, provided the original work is properly cited.

\begin{abstract}
Using estrone and pregnenolone as starting materials, some steroidal copper complexes were synthesized by the condensation of steroidal ketones with thiosemicarbazide or diazanyl pyridine and then complexation of steroidal thiosemicarbazones or steroidal diazanyl pyridines with $\mathrm{Cu}$ (II). The complexes were characterized by IR, NMR, and HRMS. The synthesized compounds were screened for their cytotoxicity against HeLa, Bel-7404, and 293T cell lines in vitro. The results show that all steroidal copper (II) complexes display obvious antiproliferative activity against the tested cancer cells. The $\mathrm{IC}_{50}$ values of complexes $\mathbf{5}$ and $\mathbf{1 2}$ against Bel-7404 (human liver carcinoma) are 5.0 and $7.0 \mu \mathrm{M}$.
\end{abstract}

\section{Introduction}

Metal-based antitumor drugs play a relevant role in antiblastic chemotherapy $[1,2]$. Cisplatin is regarded as one of the most effective drugs [3-8], even if severe toxicities and drug resistance phenomena limit its clinical use [9]. Therefore, in recent years, there has been a rapid expansion in research and development of novel metal-based anticancer drugs in order to improve clinical effectiveness, reduce general toxicity, and broaden the spectrum of activity [10-12].

Copper $(\mathrm{Cu})$ is a transition metal that can exist in oxidised and reduced states. This allows it to participate in redox and catalytic chemistry, making it a suitable cofactor for a diverse range of enzymes and molecules. $\mathrm{Cu}$ deficiency or toxicity is implicated in a variety of pathological conditions.

Steroid hormones play an important role in the biochemistry of many cancers; a number of steroidal complexes connected to a metal pharmacophore had been designed and synthesized by many research groups, and their physiological activities were evaluated $[13,14]$.
Thiosemicarbazones have received considerable attention since the discovery of their cytotoxic activity against cancer cells and bacteriostatic effects [15]. As the disruption of copper homeostasis is a pathological feature of cancer cells, copper complexes had been investigated for their potential applications as anticancer drugs [16]. Cu complexes of thiosemicarbazone (TSC) compounds had been explored as antimalarial, antifungal, antinociceptive, and antibacterial agents [17-19]. $\mathrm{Cu}$ complexes of bis(thiosemicarbazones) (CuII(btsc)s) had also been investigated as metallodrugs and diagnostic agents [20]. More recently, Adsule et al. [13] investigated the bioactivity of some new steroidal thiosemicarbazones $\mathrm{Cu}$ (II) metal complexes and discovered that some compounds had better antineoplastic activity.

In the present study, some steroidal copper complexes were synthesized by the condensation of steroidal ketones with thiosemicarbazide or diazanyl pyridine and then complexation of steroidal thiosemicarbazones or steroidal diazanyl pyridines with $\mathrm{Cu}$ (II). The synthesized compounds were screened for their cytotoxicity against HeLa, Bel-7404, and $293 \mathrm{~T}$ cell lines in vitro. 


\section{Materials and Methods}

2.1. Materials. The sterols were purchased from Sinopharm Chemical Reagent Co., Ltd., Shanghai, China. All chemicals and solvents are of analytical grade from commercial sources. All solvents were used without further purification unless otherwise specified.

2.2. Instrumentation and Methods. Melting points were determined on an X4 apparatus (Beijing Tech Instrument Co. Ltd., Beijing, China) and were uncorrected. The ${ }^{1} \mathrm{H}$ and ${ }^{13} \mathrm{C}$ NMR spectra were recorded in $\mathrm{CDCl}_{3}$ on a Bruker AV-600 spectrometer at working frequencies of 600 and $150 \mathrm{MHz}$ and a Bruker AV-300 spectrometer at working frequencies of 300 and $75 \mathrm{MHz}$, respectively. Chemical shifts are expressed in parts per million $(\delta)$ values and coupling constants $(J)$ in Hertz. Infrared spectra were measured with a Thermo Scientific Nicolet IS-10 Spectrophotometer (Thermo Scientific, USA). HREIMS was measured on an Agilent 6210 TOFMS instrument (Agilent Technologies, USA). The cell proliferation assay was undertaken by a MTT method using 96-well plates on a MLLTISKAN MK3 analysis spectrometer (Thermo Scientific, Shanghai, China).

Compounds $\mathbf{1}\left(\mathrm{L}^{1}\right)$ and $\mathbf{2}\left(\mathrm{L}^{2}\right)$ were prepared according to the method of [21].

\subsection{Synthesis}

2.3.1. General Procedure for Preparation of Steroidal Thiosemicarbazones. Steroidal ketone $(0.38 \mathrm{mmol})$ was dissolved in $40 \mathrm{~mL} 95 \%$ ethanol. After the solution was heated to $65^{\circ} \mathrm{C}$, a few drops of glacial acetic acid were added to adjust $\mathrm{pH}$ to $3-5$, and thiosemicarbazide $(1.70 \mathrm{mmol})$ was added. The mixture was stirred at $60-70^{\circ} \mathrm{C}$ for $6 \mathrm{~h}$ (the progress of the reaction was monitored by TLC, $V_{\text {ethyl acetate }}: V_{\text {petroleum ether }}$ $=1: 2$ ). Then, the reaction was terminated and majority of solvent was evaporated under reduced pressure. Suitable amount of water was added to the reaction mixture, and the product was extracted with $\mathrm{CH}_{2} \mathrm{Cl}_{2}$. The combined extract was washed with saturated $\mathrm{NaHCO}_{3}$ solution, water, and saturated brine, dried with anhydrous sodium sulfate, and evaporated under reduced pressure. The resulting residue was separated by the column chromatography using a mixture of ethyl acetate : petroleum ether $(1: 2)$ to give target products.

3 $\beta$-Hydroxypregnenolone-20-semicarbazone $\left(3, L^{3}\right)$. White solid, Yield: $78.0 \%$; m.p. $239-241^{\circ} \mathrm{C}$; IR (KBr) $v / \mathrm{cm}^{-1}$ : 3427 , $3362,3219,3162,2914,2888,1605,1515,1433,1282,1254 ;{ }^{1} \mathrm{H}$ NMR $\left(\mathrm{CDCl}_{3}, 300 \mathrm{MHz}\right) \delta: 0.60\left(3 \mathrm{H}, \mathrm{s}, 18-\mathrm{CH}_{3}\right), 0.65(3 \mathrm{H}$, $\left.\mathrm{d}, J=6.6,21-\mathrm{CH}_{3}\right), 1.21\left(3 \mathrm{H}, \mathrm{s}, 19-\mathrm{CH}_{3}\right), 3.56-3.45(1 \mathrm{H}, \mathrm{m}$, $\left.\mathrm{C}_{3}-\mathrm{H}\right), 5.37\left(1 \mathrm{H}\right.$, brs, $\left.\mathrm{C}_{6}-\mathrm{H}\right), 6.238\left(1 \mathrm{H}, \mathrm{s},-\mathrm{NH}_{2}\right), 7.22(1 \mathrm{H}$, $\left.\mathrm{s},-\mathrm{NH}_{2}\right), 8.51(1 \mathrm{H}, \mathrm{s},-\mathrm{NH}-) ;{ }^{13} \mathrm{C} \mathrm{NMR}\left(\mathrm{CDCl}_{3}, 75 \mathrm{MHz}\right) \delta$ : 179.0 (-C=S), $153.2(-\mathrm{C}=\mathrm{N}), 140.8$ (5-C), 121.4 (6-C), 71.1 (3C), 59.0 (14-C), 56.5 (17-C), 56.4 (9-C), 50.1 (13-C), 42.9 (4C), 48.8 (12-C), 42.2 (8-C), 37.2 (1-C), 36.5 (10-C), 31.8 (7-C), 31.6 (16-C, 2-C), 24.1 (15-C), 21.0 (11-C), 19.4 (21-C), 17.3 (19C), 13.2 (18-C); HREIMS: $m / z 390.2577[\mathrm{M}+\mathrm{H}]^{+}$(calcd for $\mathrm{C}_{22} \mathrm{H}_{36} \mathrm{~N}_{3} \mathrm{OS}, 390.2579$ ).
3 $\beta$-Acetyloxypregnenolone-20-semicarbazone $\left(4, L^{4}\right)$. White solid, Yield: $74.5 \%$; m.p. $254-255^{\circ} \mathrm{C}$; IR $(\mathrm{KBr}) \nu / \mathrm{cm}^{-1}$ : 3414 , $1726,1589,1506,1437,1369,1252,846 ;{ }^{1} \mathrm{H}$ NMR $(300 \mathrm{MHz}$, $\left.\mathrm{CDCl}_{3}\right) \delta: 0.58\left(\mathrm{~s}, 3 \mathrm{H}, 18-\mathrm{CH}_{3}\right), 1.02\left(\mathrm{~s}, 3 \mathrm{H}, 19-\mathrm{CH}_{3}\right), 1.91(\mathrm{~s}$, $\left.3 \mathrm{H}, 21-\mathrm{CH}_{3}\right), 2.03$ (s, 3H, $\mathrm{COCH}_{3}$ ), 4.65-4.55 (m, 1H, C3-H), $5.38(\mathrm{~d}, 1 \mathrm{H}, J=4.5, \mathrm{C} 5-\mathrm{H}), 6.52$ (br s, $\left.1 \mathrm{H},-\mathrm{NH}_{2}\right), 7.22$ (br s, $\left.1 \mathrm{H},-\mathrm{NH}_{2}\right), 8.63(\mathrm{~s}, 1 \mathrm{H},-\mathrm{NH}) ;{ }^{13} \mathrm{C} \mathrm{NMR}\left(75 \mathrm{MHz}, \mathrm{CDCl}_{3}\right) \delta$ : 13.3 (19-C), 17.5 (18-C), 19.3 (11-C), 21.0 ( $\left.\mathrm{CH}_{3} \mathrm{CO}\right), 21.4$ (21-C), 23.3 (15-C), 24.1 (16-C), 27.7 (2-C), 31.7 (8-C), 32.0 (7-C), 36.6 (10-C), 37.0 (1-C), 38.1 (4-C), 38.8 (12-C), 44.2 (13-C), 50.0 (9-C), 56.4 (17-C), 59.0 (14-C), 73.8 (3-C), 122.3 (6-C), 139.7 (5-C), 153.5 (20-C), $170.6(\mathrm{C}=\mathrm{O}), 178.9$ (C=S); HREIMS: $m / z$ 432.2633 $[\mathrm{M}+\mathrm{H}]^{+}$(calcd for $\mathrm{C}_{24} \mathrm{H}_{38} \mathrm{~N}_{3} \mathrm{O}_{2} \mathrm{~S}, 432.2685$ ).

\subsubsection{General Procedure for Preparation of Steroidal Diazanyl} Pyridine. A mixture of steroidal ketone $(1 \mathrm{mmol})$ and diazanyl pyridine $(1 \mathrm{mmol})$ in $95 \%$ ethanol $(30 \mathrm{~mL})$ was stirred at $70-80^{\circ} \mathrm{C}$ for $6 \mathrm{~h}$. After completion of the reaction, the majority of solvent was evaporated and some water was added to this solution. The mixture was extracted with $\mathrm{CH}_{3} \mathrm{COOC}_{2} \mathrm{H}_{5}$ and the extract was washed with saturated brine, dried with anhydrous sodium sulfate, and evaporated under reduced pressure. The resulting residue was chromatographed on a column of silica gel with mixture of petroleum ether/ethyl acetate $(1: 1)$ to give steroidal diazanyl pyridine.

$3 \beta$-Hydroxyoestrone-17- $\left(2^{\prime}\right.$-diazanyl)pyridine $\left(9, L^{9}\right)$. Yellow solid, Yield: $56.0 \%$; m.p. $269-271^{\circ} \mathrm{C}$; IR (KBr) $v / \mathrm{cm}^{-1}$ : 3361, 2935, 1601, 1576, 1444, 995, 871, 768; ${ }^{1} \mathrm{H}$ NMR $(600 \mathrm{MHz}$, DMSO) $\delta: 0.85\left(3 \mathrm{H}, \mathrm{s}, 18-\mathrm{CH}_{3}\right), 2.36-2.30(2 \mathrm{H}, \mathrm{m}, \mathrm{C} 6-\mathrm{H}$ and C9-H), 2.54 (1H, dd, $J=18.6,9.0, \mathrm{C} 6-\mathrm{H}), 2.70-2.69(2 \mathrm{H}, \mathrm{m}$, C16-H), $6.45(1 \mathrm{H}, \mathrm{d}, J=2.4, \mathrm{C} 4-\mathrm{H}), 6.52(1 \mathrm{H}, \mathrm{dd}, J=8.4,2.4$, C2-H), $6.67\left(1 \mathrm{H}, \mathrm{t}, J=6.0,5^{\prime}-\mathrm{Py}-\mathrm{H}\right), 7.06(1 \mathrm{H}, \mathrm{d}, J=8.4, \mathrm{C} 1-$ $\mathrm{H}), 7.07\left(1 \mathrm{H}, \mathrm{d}, J=8.4,3^{\prime}-\mathrm{Py}-\mathrm{H}\right), 7.56\left(1 \mathrm{H}, \mathrm{td}, J=8.4,1.8,4^{\prime}-\right.$ Py-H), 8.04 (1H, d, $\left.J=3.6,6^{\prime}-\mathrm{Py}-\mathrm{H}\right), 8.98$ (1H, s, -NH), 9.04 $(1 \mathrm{H}, \mathrm{s},-\mathrm{OH}) ;{ }^{13} \mathrm{C}$ NMR (150 MHz, DMSO) $\delta: 17.3$ (18-C), 23.0 (11-C), 26.1 (15-C), 26.9 (16-C), 29.2 (7-C), 34.4 (6-C), 38.0 (12-C), 40.1 (8-C), 43.8 (9-C), 44.2 (13-C), 52.2 (14-C), 106.4 (3'-Py-C), 112.8 (2-C), 114.3 (4-C), 115.0 (5'-Py-C), 126.1 (1C), 130.3 (10-C), 137.2 (4' - Рy-C), 137.6 (5-C), 147.5 (6' - Рy-C), 155.0 (3-C), 158.3 (2'-Py-C), 162.9 (17-C); HREIMS: [M+H ${ }^{+}$ 362.2250 (calcd for $\mathrm{C}_{23} \mathrm{H}_{28} \mathrm{~N}_{3} \mathrm{O}, 362.2232$ ).

$3 \beta$-Hydroxypregnenolone-20- $\left(2^{\prime}\right.$-diazanyl)pyridine $\left(\mathbf{1 0}, L^{10}\right)$. Yellow solid, Yield: 78.8\%; m.p. $234-235^{\circ} \mathrm{C}$; IR(KBr) $v / \mathrm{cm}^{-1}$ : $3406,2932,1599,1574,1442,838,768 ;{ }^{1} \mathrm{H}$ NMR $(600 \mathrm{MHz}$, DMSO) $\delta: 0.55\left(3 \mathrm{H}, \mathrm{s}, 18-\mathrm{CH}_{3}\right), 0.94\left(3 \mathrm{H}, \mathrm{s}, 19-\mathrm{CH}_{3}\right), 1.89$ $\left(3 \mathrm{H}, \mathrm{s}, 20-\mathrm{CH}_{3}\right), 3.35-3.20(1 \mathrm{H}, \mathrm{m}, \mathrm{C} 3-\alpha \mathrm{H}), 4.64(1 \mathrm{H}, \mathrm{br}$, $\mathrm{NH}), 5.27(1 \mathrm{H}, \mathrm{s}, \mathrm{C} 6-\mathrm{H}), 6.69\left(1 \mathrm{H}, \mathrm{t}, J=6.6,5^{\prime}\right.$-pyridine$\mathrm{H}), 7.06\left(1 \mathrm{H}, \mathrm{d}, J=7.2,3^{\prime}\right.$-pyridine- $\left.\mathrm{H}\right), 7.57(1 \mathrm{H}, \mathrm{t}, J=7.2$, $4^{\prime}$-pyridine- $\left.\mathrm{H}\right), 8.05\left(1 \mathrm{H}, \mathrm{d}, J=6.6,6^{\prime}\right.$-pyridine- $\left.\mathrm{H}\right), 9.07$ (s, 1H, -OH); HREIMS: $m / z$ 408.3024 $[\mathrm{M}+\mathrm{H}]^{+}$(calcd for $\mathrm{C}_{26} \mathrm{H}_{38} \mathrm{~N}_{3} \mathrm{O}, 408.3015$ ).

2.3.3. General Procedure for Preparation of Copper Complexes. Steroidal ligand $(0.1 \mathrm{mmol})$ and $0.1 \mathrm{mmol} \mathrm{CuCl} 2 \cdot 2 \mathrm{H}_{2} \mathrm{O}$ were added to $8 \mathrm{~mL}$ of methanol. The mixture was stirred for 5 hour at $70^{\circ} \mathrm{C}$. The reaction was terminated when large 
precipitant emerged. The resulting suspension was filtered, washed with ethyl acetate and water, and dried in a desiccator over phosphorus pentoxide to give target products.

$\left[\mathrm{CuL}^{1} \mathrm{Cl}_{2}\right]$ (Compound 5). Compound 5 is a mixture of $(S)$ and $(R)$-configuration isomer $\left(5-\mathrm{S}: 5-\mathrm{R}=1.7: 1,{ }^{1} \mathrm{H}\right.$ NMR data). Gray yellow solid, Yield: 55\%; m.p. $245-247^{\circ} \mathrm{C}$; IR (KBr) $\nu / \mathrm{cm}^{-1}: 3441,1604,1541,1409,1452,1280,811,616 ;{ }^{1} \mathrm{H}$ NMR (300 MHz, DMSO) $\delta: 0.81\left(\mathrm{~s}, 1.07 \mathrm{H}, 18-\mathrm{CH}_{3}, \mathrm{R}-\right), 0.86(\mathrm{~s}$, $\left.1.71 \mathrm{H}, 18-\mathrm{CH}_{3}, S-\right), 6.44(\mathrm{~s}, 1 \mathrm{H}, \mathrm{C} 4-\mathrm{H}), 6.50$ (d, $1 \mathrm{H}, J=4.5$, C2-H), 7.05 (d, $1 \mathrm{H}, J=4.5, \mathrm{C} 1-\mathrm{H}), 7.77$ (s, 0.19H, $-\mathrm{NH}_{2}, R-$ ), 8.00 (s, 0.31H, $-\mathrm{NH}_{2}, S$-), 8.65 (s, 0.36H, $-\mathrm{NH}_{2}, S-$ ), 8.85 (s, $\left.0.25 \mathrm{H},-\mathrm{NH}_{2}, R-\right), 9.03$ (s, $\left.1 \mathrm{H},-\mathrm{OH}\right), 10.30$ (s, 0.34H, -NH-, $S-), 10.64$ (s, 0.20H, -NH-, $R-$ ).

$\left[\mathrm{CuL}^{2} \mathrm{Cl}_{2}\right]$ (Compound 6). Compound $\mathbf{6}$ is a mixture of $(S)$ and $(R)$-configuration isomer $\left(6-\mathrm{S}: 6-\mathrm{R}=1.5: 1,{ }^{1} \mathrm{H} \mathrm{NMR}\right.$ data). Gray solid, Yield: $66.7 \%$; m.p. $189-190^{\circ} \mathrm{C}$; IR (KBr) $\nu / \mathrm{cm}^{-1}: 3416,2927,1604,1534,1496,1447,876,816,751 ;{ }^{1} \mathrm{H}$ NMR (600 MHz, DMSO): 0.85 (s, 1.85H, 18- $\mathrm{CH}_{3}, S-$ ), 1.01 (s, $\left.1.25 \mathrm{H}, 18-\mathrm{CH}_{3}, R-\right), 2.21$ (s, 3H, $\left.\mathrm{COCH}_{3}\right), 6.79(\mathrm{~s}, 1 \mathrm{H}, \mathrm{C} 4-\mathrm{H})$, $6.83(\mathrm{~d}, 1 \mathrm{H}, J=6.0, \mathrm{C} 2-\mathrm{H}), 7.29(\mathrm{~s}, 1 \mathrm{H}, J=6.0, \mathrm{C} 1-\mathrm{H}), 7.73$ (s, $\left.0.38 \mathrm{H},-\mathrm{NH}_{2}\right), 8.04\left(\mathrm{~s}, 0.45 \mathrm{H},-\mathrm{NH}_{2}, \mathrm{~S}-\right), 8.68(\mathrm{~s}, 0.48 \mathrm{H}$, $\left.\mathrm{NH}_{2}, S-\right), 8.84$ (s, 0.33H, $\left.-\mathrm{NH}_{2}, R-\right), 9.023$ (s, 1H, -OH), 10.31 (s, 0.40H, -NH-, S-), 10.63 (s, 0.33H, -NH-, R-); ${ }^{13} \mathrm{C}$ NMR (150 MHz, DMSO) $\delta: 16.5$ (18-C), $20.6\left(\mathrm{CH}_{3} \mathrm{CO}\right), 22.3$ (11-C), 26.1 (15-C), 26.4 (16-C), 28.6 (7-C), 28.8 (6-C), 33.5 (12-C), 37.1 (8-C), 37.5 (8-C), 43.1 (9-C), 44.6 (13-C), 51.6 (14-C), 118.6 (2-C), 121.2 (4-C), 126.0 (1-C), 136.8 (5-C), 137.4 (10-C), 148.0 (3-C), 154.7 (17-C), $169.1\left(\mathrm{COCH}_{3}\right), 170.1(\mathrm{C}=\mathrm{S}), 171.3$ (C=S).

$\left[\mathrm{CuL}^{3} \mathrm{Cl}_{2}\right]$ (Compound 7). Compound 7 is a mixture of $(S)$ and $(R)$-configuration isomer $\left(7-\mathrm{S}: 7-\mathrm{R}=1: 1.5,{ }^{1} \mathrm{H} \mathrm{NMR}\right.$ data). Gray solid, Yield: $60.2 \%$; m.p. $189-191^{\circ} \mathrm{C}$; IR (KBr) $\nu / \mathrm{cm}^{-1}: 3319,1604,1531,1434,1369,1290,1050,950 ;{ }^{1} \mathrm{H}$ NMR (600 MHz, DMSO) $\delta: 0.51\left(\mathrm{~s}, 1.2 \mathrm{H}, 18-\mathrm{CH}_{3}, S-\right), 0.68(\mathrm{~s}, 1.8 \mathrm{H}$, $\left.18-\mathrm{CH}_{3}, R-\right), 0.91$ (s, 3H, 19- $\mathrm{CH}_{3}$ ), 1.96 (s, 1.2H, 21- $\mathrm{CH}_{3}, \mathrm{~S}-$ ), 2.00 (s, 1.8H, 21- $\left.\mathrm{CH}_{3}, R-\right), 3.23-3.12(\mathrm{~m}, 1 \mathrm{H}, \mathrm{C} 3-\mathrm{H}), 4.61$ (s, $1 \mathrm{H}, \mathrm{OH}), 5.24$ (s, 1H, C6-H), 7.75 (s, $\left.0.6 \mathrm{H},-\mathrm{NH}_{2}, R-\right), 8.01$ (s, $\left.0.4 \mathrm{H},-\mathrm{NH}_{2}, \mathrm{~S}-\right), 8.73\left(\mathrm{~s}, 0.4 \mathrm{H},-\mathrm{NH}_{2}, S-\right), 8.95\left(\mathrm{~s}, 0.6 \mathrm{H},-\mathrm{NH}_{2}\right.$, $R-), 10.29$ (s, 0.4H, -NH-, S-), 10.89 (s, 0.6H, -NH-, R-); ${ }^{13} \mathrm{C}$ NMR (150 MHz, DMSO) $\delta: 12.7$ (19-C), 18.7 (18-C), 20.3 (11C), 20.8 (21-C), 21.9 (15-C), 23.7 (16-C), 27.0 (2-C), 31.0 (8-C), 31.1 (7-C), 35.8 (1-C), 36.6 (10-C), 37.4 (4-C), 41.9 (12-C), 43.0 (13-C), 49.2 (9-C), 55.7 (17-C), 58.2 (14-C), 69.7 (3-C), 121.7 (6-C), 139.2 (5-C), 140.9 (20-C), 169.5 (C=S); HREIMS: $m / z$ $521.1197[\mathrm{M}-\mathrm{H}]^{-}$(calcd for $\mathrm{C}_{22} \mathrm{H}_{34} \mathrm{Cl}_{2} \mathrm{CuN}_{3} \mathrm{OS}$, 521.1196).

$\left[\mathrm{CuL}^{4} \mathrm{Cl}_{2}\right]$ (Compound 8). Compound $\mathbf{8}$ is a mixture of $(S)$ and $(R)$-configuration isomer $\left(8-S: 8-\mathrm{R}=1.3: 1,{ }^{1} \mathrm{H}\right.$ NMR data). Gray solid, Yield: $75 \%$; m.p. $163-165^{\circ} \mathrm{C}$; IR (KBr) $\nu / \mathrm{cm}^{-1}: 3424,1723,1596,1534,1432,1364,1040 ;{ }^{1} \mathrm{H}$ NMR (600 MHz, DMSO) $\delta: 0.50\left(\mathrm{~s}, 1.7 \mathrm{H}, 18-\mathrm{CH}_{3}, S-\right), 0.671(\mathrm{~s}, 1.3 \mathrm{H}$, $\left.18-\mathrm{CH}_{3}, R-\right), 0.94\left(\mathrm{~s}, 3 \mathrm{H}, 19-\mathrm{CH}_{3}\right), 1.95$ (s, 1.7H, 21- $\mathrm{CH}_{3}, S-$ ), 1.98 (s, 1.3H, 21- $\left.\mathrm{CH}_{3}, R-\right), 2.24\left(\mathrm{~s}, 3 \mathrm{H}, \mathrm{COCH}_{3}\right), 7.754$ (s, $\left.0.43 \mathrm{H},-\mathrm{NH}_{2}, R-\right), 7.962\left(\mathrm{~s}, 0.49 \mathrm{H},-\mathrm{NH}_{2}, R-\right), 8.666(\mathrm{~s}, 0.51 \mathrm{H}$, $\left.-\mathrm{NH}_{2}, S-\right), 8.929$ (s, 0.52H, $\left.-\mathrm{NH}_{2}, S-\right), 10.276$ (s, 0.56H, -NH, S-), 10.881 (s, 0.40H, -NH, R-); ${ }^{13} \mathrm{C}$ NMR (150 MHz, DMSO) $\delta$ : 12.7 (19-C), 18.7 (18-C), 20.3 (11-C), 20.8 (21-C), 21.9 (15-C),
23.7 (16-C), 27.0 (2-C), 31.0 (8-C), 31.1 (7-C), 35.8 (1-C), 36.6 (10-C), 37.4 (4-C), 41.9 (12-C), 43.0 (13-C), 49.2 (9-C), 55.7 (17-C), 58.2 (14-C), 69.7 (3-C), 121.7 (6-C), 139.2 (5-C), 140.9 (20-C), $169.5(\mathrm{C}=\mathrm{S})$.

[CuL ${ }^{9} \mathrm{Cl}_{2}$ ] (Compound 11). Gray solid, Yield: 62.3\%; m.p. 210-212 ${ }^{\circ} \mathrm{C}$; IR (KBr) $v / \mathrm{cm}^{-1}: 3441,3324,2962,1654,1611,1559$, $1534,1501,1442,916,848,744 ;{ }^{1} \mathrm{H}$ NMR (600 MHz, DMSO): $1.51\left(3 \mathrm{H}, \mathrm{s}, 18-\mathrm{CH}_{3}\right), 2.84-2.73(3 \mathrm{H}, \mathrm{m}, \mathrm{C} 16-\mathrm{H}$ and $\mathrm{C} 6-\mathrm{H})$, $6.49(1 \mathrm{H}, \mathrm{s}, \mathrm{C} 4-\mathrm{H}), 6.56(1 \mathrm{H}$, br s, C2-H), $7.12(1 \mathrm{H}, \mathrm{d}, J=6.0$, $\left.5^{\prime}-\mathrm{Py}-\mathrm{H}\right), 7.45\left(1 \mathrm{H}\right.$, br s, $\left.3^{\prime}-\mathrm{Py}-\mathrm{H}\right), 7.86\left(1 \mathrm{H}\right.$, br s, $\left.4^{\prime}-\mathrm{Py}-\mathrm{H}\right)$, $8.08(1 \mathrm{H}, \mathrm{d}, J=8.4, \mathrm{C} 1-\mathrm{H}), 8.74\left(1 \mathrm{H}\right.$, br s, $\left.6^{\prime}-\mathrm{Py}-\mathrm{H}\right), 9.11(1 \mathrm{H}$, s, -NH); ${ }^{13} \mathrm{C}$ NMR (150 MHz, DMSO) $\delta$ : 16.1 (18-C), 20.6 (15C), 20.8 (11-C), 25.9 (7-C), 26.1 (6-C), 29.3 (12-C), 35.9 (16C), 38.3 (8-C), 42.4 (13-C), 65.0 (14-C), 113.1 (2-C), 114.7 (4C), 115.3 (3' - Py-C), 117.2 (5' -Py-C), 125.2 ( $4^{\prime}$-Py-C), 126.2 (1C), 129.3 (10-C), 133.5 (6' - Рy-C), 137.0 (5-C), 143.9 (2' - Рy-C), 146.2 (17-C), 155.3 (3-C).

[CuL ${ }^{10} \mathrm{Cl}_{2}$ ] (Compound 12). Green solid, Yield: 30.7\%; m.p. 224-225 ${ }^{\circ} \mathrm{C}$; ${ }^{1} \mathrm{H}$ NMR (600 MHz, DMSO) $\delta: 0.96$ (3H, s, 18$\left.\mathrm{CH}_{3}\right), 1.00\left(3 \mathrm{H}, \mathrm{s}, 19-\mathrm{CH}_{3}\right), 2.08\left(3 \mathrm{H}, \mathrm{s}, 20-\mathrm{CH}_{3}\right), 3.37-3.18$ $(1 \mathrm{H}, \mathrm{m}, \mathrm{C} 3-\alpha \mathrm{H}), 4.63(1 \mathrm{H}, \mathrm{s}, \mathrm{OH}), 5.24(1 \mathrm{H}, \mathrm{s}, \mathrm{C} 6-\mathrm{H}), 6.21$ $(0.36 \mathrm{H}, \mathrm{t}, J=4.8), 6.33\left(0.33 \mathrm{H}, \mathrm{d}, J=6.6,5^{\prime}-\mathrm{Py}-\mathrm{H}\right), 7.32$ (0.33H, br s, $\left.4^{\prime}-\mathrm{Py}-\mathrm{H}\right), 7.69\left(0.32 \mathrm{H}, \mathrm{dd}, J=24.6,6.6,3^{\prime}-\mathrm{Py}-\right.$ H), $8.49\left(0.60 \mathrm{H}, \mathrm{s}, 6^{\prime}-\mathrm{Py}-\mathrm{H}\right), 9.07(0.60 \mathrm{H}, \mathrm{s}), 9.23(0.60 \mathrm{H}, \mathrm{d}$, $J=6.6), 9.79(0.57 \mathrm{H}, \mathrm{s},-\mathrm{NH}) ;{ }^{13} \mathrm{C} \mathrm{NMR}(150 \mathrm{MHz}, \mathrm{DMSO})$ $\delta$ : 14.2 (21-C), 18.9 (18-C), 19.7 (11-C), 19.8 (19-C), 20.3 (15C), 22.2 (16-C), 30.7 (8-C), 31.0 (2-C), 31.1 (7-C), 35.8 (10-C), 36.6 (1-C), 37.8 (12-C), 41.9 (13-C), 42.8 (4-C), 49.2 (17-C), 55.4 (9-C), 57.8 (14-C), 69.7 (3-C), 117.8 (3'-Py-C), 119.8 (5' Py-C), 122.0 (6-C), 129.2 (4' - Py-C), 140.9 (5-C), 141.0 (6' - Py- $^{\prime}$ C), 149.9 (20-C), 151.9 (2' - Py-C).

2.4. Cytotoxicity Assay. The antiproliferative activity of all $\mathrm{Cu}$ (II) metal complexes and steroidal thiosemicarbazones on Bel-7404 (human liver carcinoma), HeLa (human cervical carcinoma), and HEK-293T (normal kidney epithelial) cell lines was determined by using the MTT method and cisplatin as a positive control. The detailed procedure had been reported in our previous work [22].

\section{Results and Discussion}

3.1. Synthesis and Characterization. The synthetic route and the structures of complexes 5-8 are outlined in Scheme 1. The steroidal thiosemicarbazones 1-4 were obtained by reacting estrone and pregnenolone or their ester with thiosemicarbazide and then the reaction of compounds 1-4 with $\mathrm{CuCl}_{2} \cdot 2 \mathrm{H}_{2} \mathrm{O}$ gave steroidal copper $(\mathrm{Cu}(\mathrm{II}))$ complexes $5-\mathbf{8}$ as a mixture of $(R)$ - and $(S)$-configuration isomers, respectively. The structures of 5-8 are confirmed by analysis of IR, NMR, and HRMS. Compared with the signal of - NH- in ${ }^{1} \mathrm{H}$ NMR for ligand 3 , the proton chemical shift of $-\mathrm{NH}$ - for compound 7 migrates to $\delta 10.29(\mathrm{~s}, 0.4 \mathrm{H})$ and $10.89(\mathrm{~s}, 0.6 \mathrm{H}) \mathrm{ppm}$ of downfield from $\delta 8.51 \mathrm{ppm}$ of upfield due to the effect of $\mathrm{Cu}$ (II) and demonstrates the formation of $\mathrm{L}^{3}-\mathrm{Cu}$ (II) complex. The resonances showing of 10.29 and $10.89 \mathrm{ppm}$ belongs to the chemical shift of $(S)$ - and $(R)-7$, respectively, and illustrates 


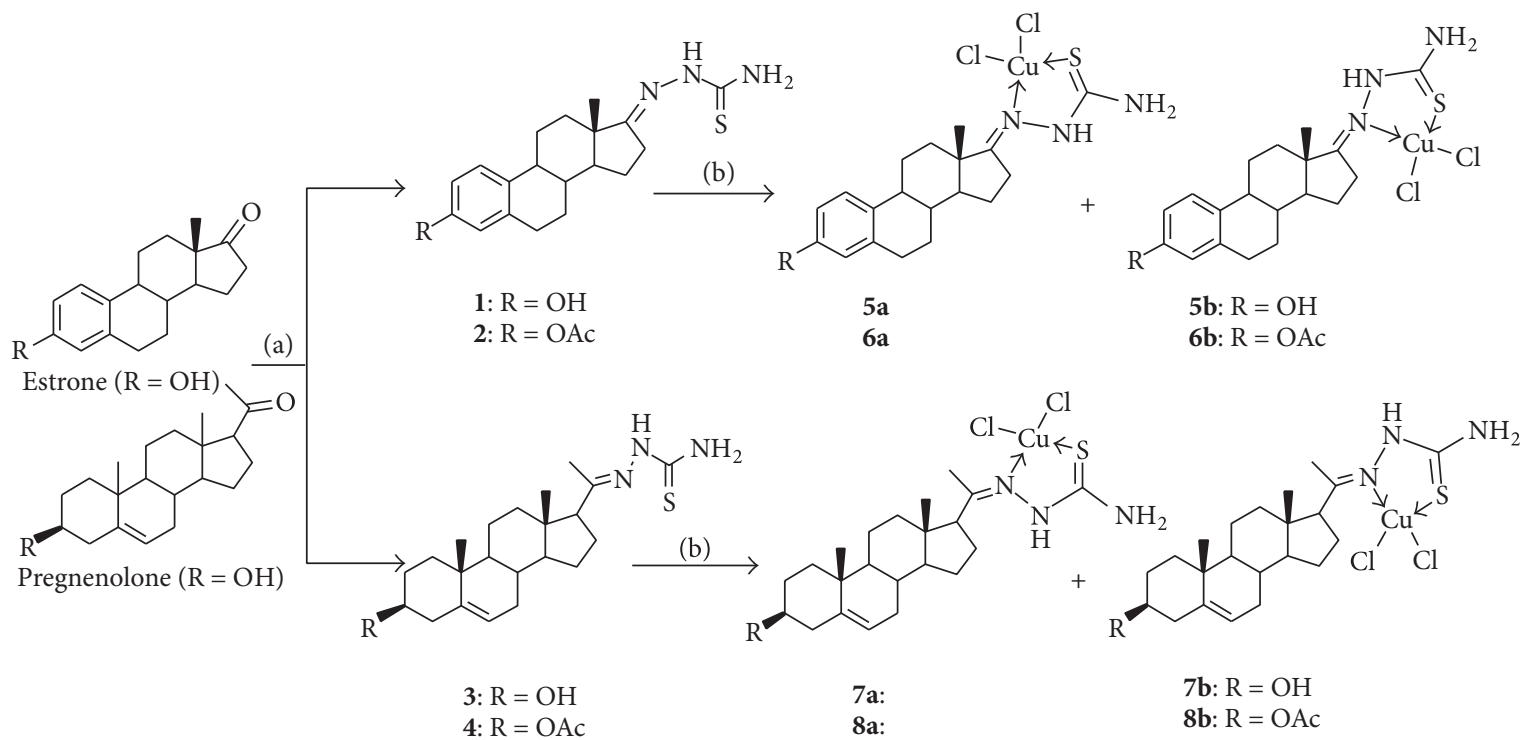

(S)-configuration

(R)-configuration

Scheme 1: Synthesis of complexes 5-8. Reagents and conditions: (a) thiosemicarbazide, acetic acid, and ethanol; $(b) \mathrm{CuCl}_{2} \cdot 2 \mathrm{H}_{2} \mathrm{O}$, $\mathrm{CH}_{3} \mathrm{OH} / \mathrm{CHCl}_{3}=1: 1$.<smiles>CC(=O)C1CCC2C3CC=C4CC(O)CC[C@]4(C)C3CC[C@]12C</smiles>

Scheme 2: Synthesis of complexes 11-12. Reagents and conditions: (a) 2-hydrazinopyridine, acetic acid, and ethanol; $(\mathrm{b}) \mathrm{CuCl}_{2} \cdot 2 \mathrm{H}_{2} \mathrm{O}$, $\mathrm{CH}_{3} \mathrm{OH} / \mathrm{CHCl}_{3}=1: 1$.

further that compound 7 is the mixture of $(S)$ - and $(R)$ configuration isomers (7-S:7-R $=1: 1.5,{ }^{1} \mathrm{H}$ NMR data) from the chemical shift of $18-\mathrm{CH}_{3}$ and $21-\mathrm{CH}_{3}\left(18-\mathrm{CH}_{3}: 0.51(1.2 \mathrm{H}\right.$, $S-), 0.68(1.8 \mathrm{H}, R-)$ ppm; $21-\mathrm{CH}_{3}: 1.96(1.2 \mathrm{H}, S-), 2.00(1.8 \mathrm{H}$, $R-) \mathrm{ppm}$ ).

In order to investigate the effect of different ligand on the antiproliferative activity of complexes, $3 \beta$-hydroxyoestrone-17-( $2^{\prime}$-diazanyl)pyridine-Copper(II) 11 and $3 \beta$-Hydroxypregnenolone-20-( $2^{\prime}$-diazanyl) pyridine-Copper (II) 12 were synthesized according to Scheme 2. Ligands $\mathbf{9}$ and $\mathbf{1 0}$ were obtained as a $(E)$-configuration by reacting estrone or pregnenolone with 2-hydrazinopyridine. Furthermore, the reaction of compounds 9 and 10 with $\mathrm{CuCl}_{2} \cdot 2 \mathrm{H}_{2} \mathrm{O}$ gave steroidal copper ( $\mathrm{Cu}(\mathrm{II}))$ complexes 11 and 12 as $(S)$ - and (R)configuration, respectively. The structures of $\mathbf{1 1}$ and $\mathbf{1 2}$ were confirmed by analysis of IR, NMR, and HRMS.

3.2. Cytotoxic Activity In Vitro. The antiproliferative activities of all steroidal $\mathrm{Cu}(\mathrm{II})$ metal complexes were determined in vitro on Bel-7404 (human liver carcinoma), HeLa (human cervical carcinoma), and 293T (normal kidney epithelial) cell lines. The MTT method was used to assay the antiproliferative activity and cisplatin was used as a positive control. The results are summarized as $\mathrm{IC}_{50}$ values in $\mu \mathrm{M}$ in Table 1 .

From the data shown in Table 1, all steroidal copper $(\mathrm{Cu}$ (II)) complexes show an obvious antiproliferative activity 
TABLE 1: Cytotoxicity ${ }^{\mathrm{a}}$ of steroidal thiosemicarbazone and its $\mathrm{Cu}-$ complexes in vitro $\left(\mathrm{IC}_{50}: \mu \mathrm{M}\right)^{\mathrm{b}}$.

\begin{tabular}{lccc}
\hline Compounds & Bel-7404 & HeLa & $293 \mathrm{~T}$ \\
\hline 1 & 19 & 34 & ND \\
2 & $>200$ & 42 & $>200$ \\
5 & 5.0 & 11 & 27 \\
6 & 13 & 7.7 & 11 \\
7 & 9.5 & 6.8 & 15.3 \\
8 & 14.1 & 10.6 & 9.1 \\
11 & 14 & $\mathrm{ND}$ & 14 \\
12 & 7.0 & $\mathrm{ND}$ & 9.0 \\
Cisplatin & 23.2 & 10.1 & 10.3 \\
\hline
\end{tabular}

${ }^{a}$ Cytotoxicity as $\mathrm{IC}_{50}$ for each cell line is the concentration of compound which reduced by $50 \%$ the optical density of treated cells with respect to untreated cells using the MTT assay. ${ }^{b}$ Data represent the mean values of the three independent determinations. ND: not determined.

against the tested cancer cells. The compounds 5-7 display a better activity to Bell-7404 and HeLa cells compared to that of cisplatin. Comparing the antiproliferative activity of steroidal thiosemicarbazone ligands with that of their copper (II) complexes, we can see that steroidal thiosemicarbazone copper (II) complexes show a better inhibiting activity compared to their homologous ligands ( 1 versus 5 and 2 versus 6). Particularly, complexes 5 and 7 show an excellent antiproliferative activity against Bel-7404 cells with the $\mathrm{IC}_{50}$ values of 5.0 and $9.5 \mu \mathrm{M}$, and complexes 6 and 7 possess $\mathrm{IC}_{50}$ values of 7.7 and $6.8 \mu \mathrm{M}$ against HeLa cells.

Comparing compound 7 with compound 8 , we can observe that after 3-hydroxyl group of 7 was converted into 3acetoxy group (compound $\mathbf{8}$ ), the antiproliferative activity of the compound was remarkably decreased and the cytotoxicity to normal cells $293 \mathrm{~T}$ was increased. The result shows that 3-hydroxyl of the compound to the antiproliferative activity plays an important role.

Unfortunately, these steroidal copper ( $\mathrm{Cu}(\mathrm{II})$ ) complexes to normal kidney epithelial cells (293T) show similar cytotoxicity except for compound $\mathbf{5}$ which exhibits a smaller activity to $293 \mathrm{~T}$ cells compared to cisplatin $(27 \mu \mathrm{M}$ versus $10.3 \mu \mathrm{M})$.

\section{Conclusion}

In conclusion, using estrone and pregnenolone as starting materials, through different chemical methods, some steroidal copper (II) complexes were synthesized and characterized by IR, NMR, and HRMS. Their antiproliferative activities were assayed by MTT method. The results show that all steroidal copper (II) complexes display obvious antiproliferative activity against the tested cancer cells, and compounds 5-7 show better cytotoxicity compared to a positive control, cisplatin. Among them, complexes $\mathbf{5}$ and $\mathbf{1 2}$ show an excellent antiproliferative activity against Bel-7404 cells with the $\mathrm{IC}_{50}$ values of 5.0 and $7.0 \mu \mathrm{M}$, and complexes 6 and 7 possess $\mathrm{IC}_{50}$ values of 7.7 and $6.8 \mu \mathrm{M}$ against HeLa cells. The result may be useful for the design of novel chemotherapeutic drugs.

\section{Conflicts of Interest}

The authors declare that they have no conflicts of interest.

\section{Acknowledgments}

The authors acknowledge the financial support of the National Natural Science Foundation of China (no. 21462009), Natural Science Fund of Guangxi province (no. 2014GXNSFAA118052), and the Guangxi Colleges and Universities Key Laboratory of Synthetic and Natural Functional Molecular Chemistry.

\section{References}

[1] B. Rosenberg, L. Van Camp, and T. Krigas, "Inhibition of cell division in Escherichia coli by electrolysis products from a platinum electrode," Nature, vol. 205, no. 4972, pp. 698-699, 1965.

[2] B. Rosenberg, L. Van Camp, E. B. Grimley, and A. J. Thomson, "The inhibition of growth or cell division in Escherichia coli by different ionic species of platinum(IV) complexes," Journal of Biological Chemistry, vol. 242, no. 6, pp. 1347-1352, 1967.

[3] S. M. Sbovata, F. Bettio, M. Mozzon et al., "Cisplatinum and transplatinum complexes with benzyliminoether ligands; synthesis, characterization, structure-activity relationships, and in vitro and in vivo antitumor efficacy," Journal of Medicinal Chemistry, vol. 50, no. 19, pp. 4775-4784, 2007.

[4] D. Kovala-Demertzi, A. Galani, N. Kourkoumelis, J. R. Miller, and M. A. Demertzis, "Synthesis, characterization, crystal structure and antiproliferative activity of platinum(II) complexes with 2-acetylpyridine-4-cyclohexyl-thiosemicarbazone," Polyhedron, vol. 26, no. 12, pp. 2871-2879, 2007.

[5] X. Liu, H. Shen, H. Zhu, K. Cui, and S. Gou, "In vitro cytotoxicity study on platinum(II) complexes with epoxysuccinates as leaving groups," Bioorganic and Medicinal Chemistry Letters, vol. 17, no. 14, pp. 3831-3834, 2007.

[6] J.Zhang and X. Zhao, "Synthesis, cytotoxicity and DNA-binding levels of ammine/propylamine platinum(II) complexes with carboxylates," European Journal of Medicinal Chemistry, vol. 42, no. 2, pp. 286-291, 2007.

[7] A. S. Abu-Surrah and M. Kettunen, "Platinum group antitumor chemistry: design and development of new anticancer drugs complementary to cisplatin," Current Medicinal Chemistry, vol. 13, no. 11, pp. 1337-1357, 2006.

[8] G. Momekov, A. Bakalova, and M. Karaivanova, "Novel approaches towards development of non-classical platinum-based antineoplastic agents: design of platinum complexes characterized by an alternative DNA-binding pattern and/or tumortargeted cytotoxicity," Current Medicinal Chemistry, vol. 12, no. 19, pp. 2177-2191, 2005.

[9] K. Barabas, R. Milner, D. Lurie, and C. Adin, "Cisplatin: a review of toxicities and therapeutic applications," Veterinary and Comparative Oncology, vol. 6, no. 1, pp. 1-18, 2008.

[10] J. Shao, Z.-Y. Ma, A. Li et al., “Thiosemicarbazone Cu(II) and $\mathrm{Zn}$ (II) complexes as potential anticancer agents: syntheses, crystal structure, DNA cleavage, cytotoxicity and apoptosis induction activity," Journal of Inorganic Biochemistry, vol. 136, pp. 13-23, 2014.

[11] G. Tamasi, C. Bernini, G. Corbini et al., "Synthesis, spectroscopic and DFT structural characterization of two novel 
ruthenium(III) oxicam complexes. In vivo evaluation of antiinflammatory and gastric damaging activities," Journal of Inorganic Biochemistry, vol. 134, pp. 25-35, 2014.

[12] B. Božić, J. Rogan, D. Poleti, N. Trišović, B. Božić, and G. Ušćumlić, "Synthesis, characterization and antiproliferative activity of transition metal complexes with 3-(4,5-diphenyl-1,3oxazol-2-yl)propanoic acid (oxaprozin)," Chemical and Pharmaceutical Bulletin, vol. 60, no. 7, pp. 865-869, 2012.

[13] S. Adsule, S. Banerjee, F. Ahmed, S. Padhye, and F. H. Sarkar, "Hybrid anticancer agents: isothiocyanate-progesterone conjugates as chemotherapeutic agents and insights into their cytotoxicities," Bioorganic and Medicinal Chemistry Letters, vol. 20, no. 3, pp. 1247-1251, 2010.

[14] G. A. G. Santos, A. P. Murray, C. A. Pujol, E. B. Damonte, and M. S. Maier, "Synthesis and antiviral activity of sulfated and acetylated derivatives of $2 \beta, 3 \alpha$-dihydroxy- $5 \alpha$-cholestane," Steroids, vol. 68 , no. 2, pp. 125-132, 2003.

[15] H. Huang, Q. Chen, X. Ku et al., "A series of $\alpha$-heterocyclic carboxaldehyde thiosemicarbazones inhibit topoisomerase II $\alpha$ catalytic activity," Journal of Medicinal Chemistry, vol. 53, no. 8, pp. 3048-3064, 2010.

[16] C. Duncan and A. R. White, "Copper complexes as therapeutic agents," Metallomics, vol. 4, no. 2, pp. 127-138, 2012.

[17] D. X. West and A. E. Liberta, "Thiosemicarbazone complexes of copper(II): structural and biological studies," Coordination Chemistry Reviews, vol. 123, no. 1-2, pp. 49-71, 1993.

[18] H. Beraldo and D. Gambino, "The wide pharmacological versatility of semicarbazones, thiosemicarbozones and their metal complexes," Mini-Reviews in Medicinal Chemistry, vol. 4, no. 1, pp. 31-39, 2004.

[19] F. Tisato, C. Marzano, M. Porchia, M. Pellei, and C. Santini, "Copper in diseases and treatments, and copper-based anticancer strategies," Medicinal Research Reviews, vol. 30, no. 4, pp. 708-749, 2010.

[20] J. L. Dearling, J. S. Lewis, G. E. Mullen, M. J. Welch, and P. J. Blower, "Copper bis(thiosemicarbazone) complexes as hypoxia imaging agents: structure-activity relationships," Journal of Biological Inorganic Chemistry, vol. 7, no. 3, pp. 249-259, 2002.

[21] Y. Huang, E. Kong, C. Gan, Z. Liu, Q. Lin, and J. Cui, "Synthesis and antiproliferative activity of steroidal thiosemicarbazone platinum (Pt(II)) complexes," Bioinorganic Chemistry and Applications, vol. 2015, Article ID 742592, 7 pages, 2015.

[22] C. Gan, J. Cui, S. Su et al., "Synthesis and antiproliferative activity of some steroidal thiosemicarbazones, semicarbazones and hydrozones," Steroids, vol. 87, pp. 99-107, 2014. 

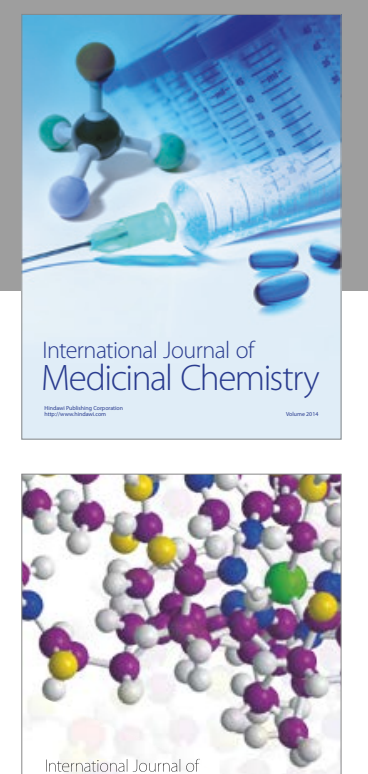

Carbohydrate Chemistry

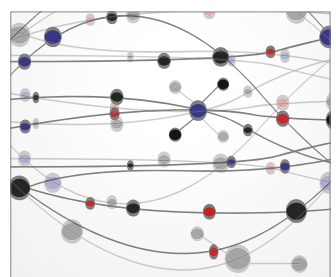

The Scientific World Journal
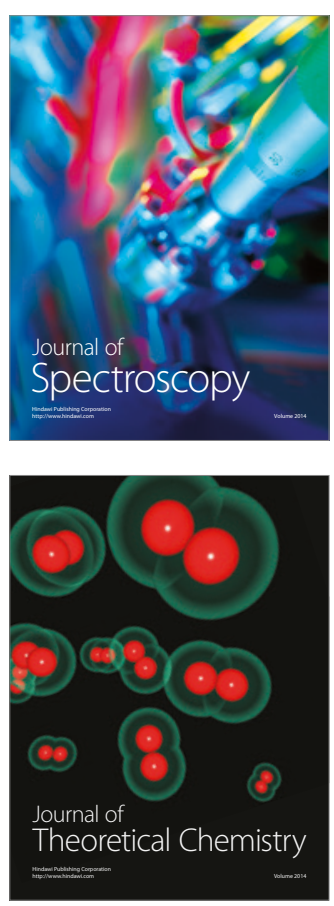
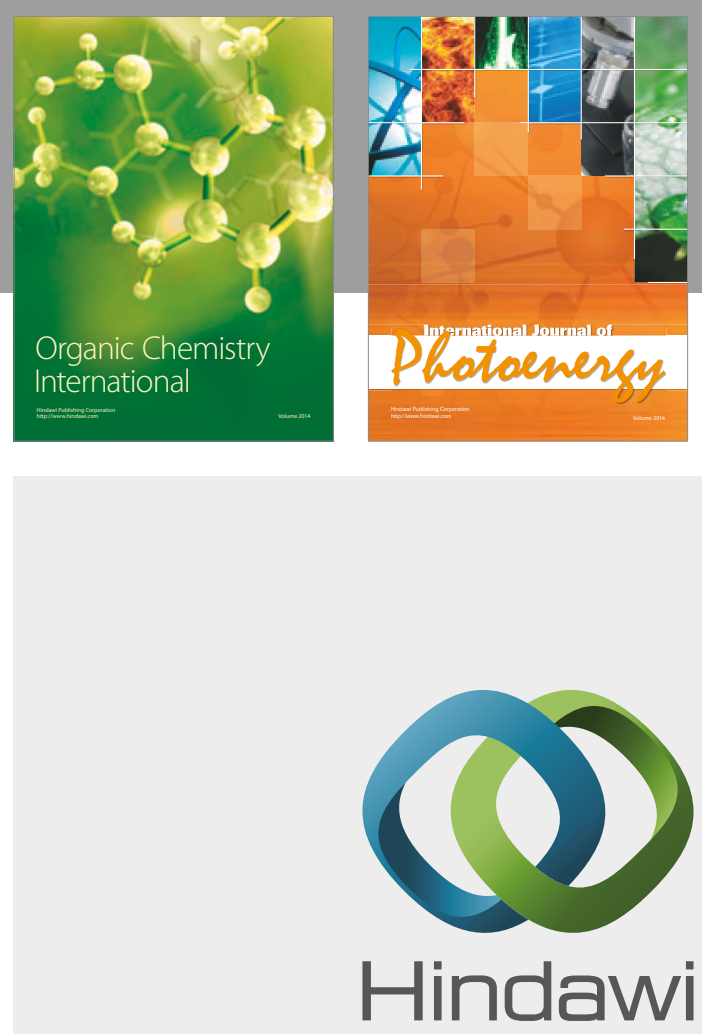

Submit your manuscripts at

https://www.hindawi.com

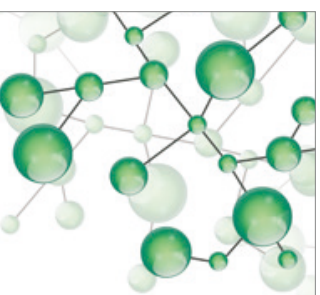

International Journal of

Inorganic Chemistry

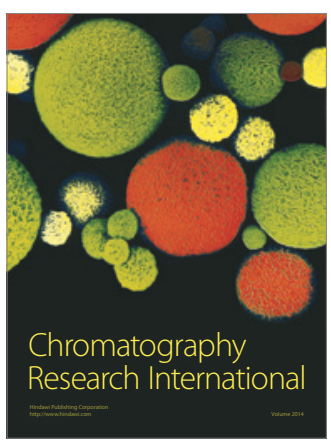

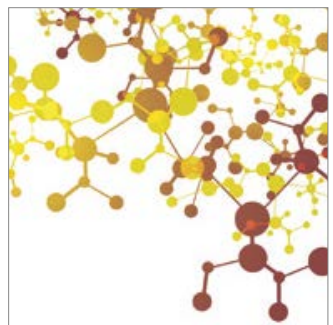

Applied Chemistry
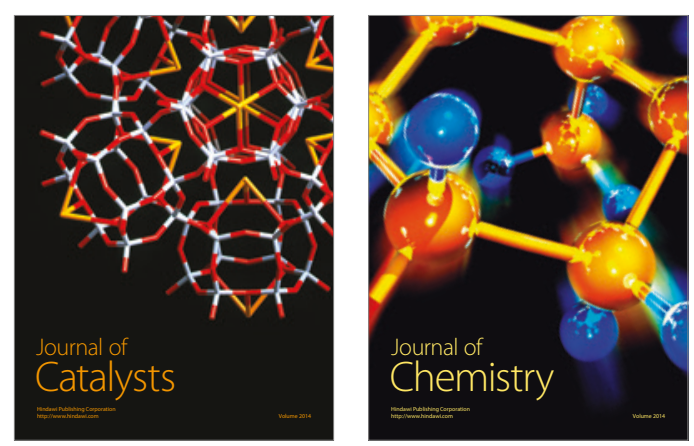
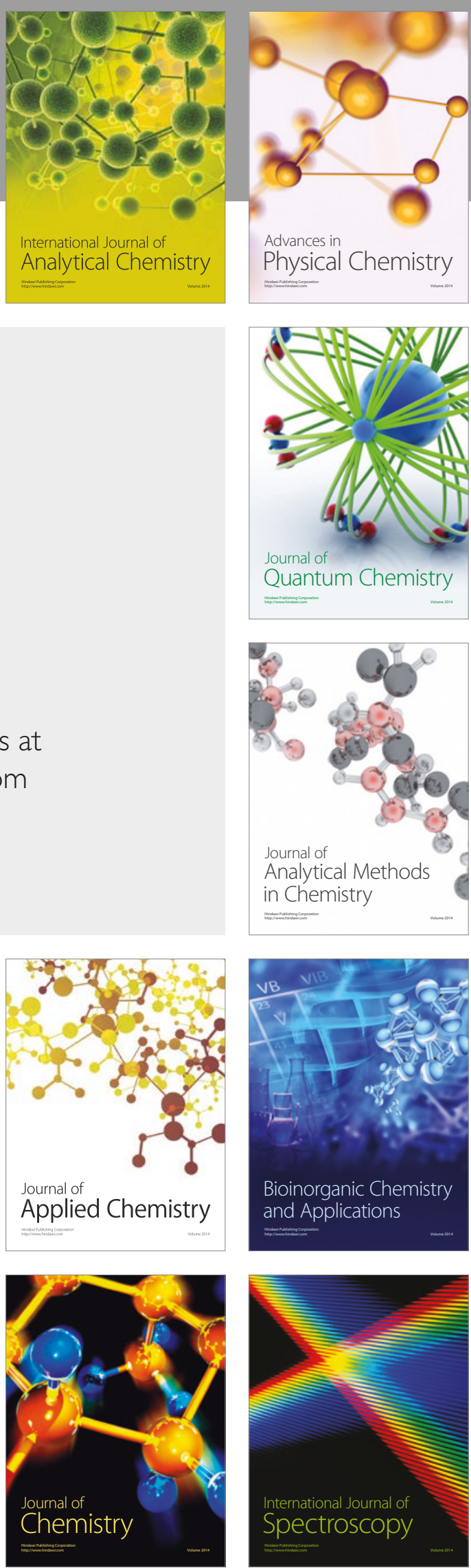